\title{
Adaptation of International Students to University Reality in Kazakhstan (on the Example of WKMU)
}

\author{
Jay Kumar Gahwal ${ }^{1}$ (D) , Anara Urkunova ${ }^{2}$ (D), Gulzhana Jenalayeva ${ }^{3}$ (D) $\triangle$, Aigul Kupenova 9 (D) and \\ Gulmira Nurgaliyeva ${ }^{5}$ (D) \\ ${ }^{1}$ General Medicine Student, West Kazakhstan Marat Ospanov Medical University \\ ${ }^{245}$ Senior Lecturer, the Department of Languages, West Kazakhstan Marat Ospanov Medical University; the Department of the \\ English and German languages \\ ${ }^{3} \mathrm{PhD}$, Associate Professor, the Department of Languages, West Kazakhstan Marat Ospanov Medical University; the Department \\ of the English and German languages, K. Zhubanov Aktobe Regional University, Aktobe city, the Republic of Kazakhstan
}

$\triangle$ Corresponding Author: Gulzhana Jenalayeva, E-mail: kuzembayeva@mail.ru

\section{ARTICLE INFORMATION}

Received: April 08, 2021

Accepted: May 14, 2021

Volume: 3

Issue: 5

DOI: 10.32996/jhsss.2021.3.5.4

\section{KEYWORDS}

International students, adaptation, socio-cultural adaptation, higher education, adjustment, the university

\section{ABSTRACT}

One of the most important topics for Kazakhstani universities in the context of internationalization of higher education is the successful adaptation of international students to a university setting. A high level of students' adaptation, socially and psychologically comfortable conditions for them may increase the number of international students in Kazakhstan from the perspective. The article analyzes the main aspects of international students' socio-cultural adaptation at the West Kazakhstan Marat Ospanov Medical University, Aktobe, the Republic of Kazakhstan (WKMU). A sociological survey was conducted among the Indian students of the Faculty of General Medicine. Challenges of international students at WKMU include the language barrier, the difference in assessment, and education systems in India and Kazakhstan. A favourable condition for the socio-cultural adaptation of international students at WKMU is the organization of intercultural interaction and cooperation of students in the educational space of the university. The results of the study are offered to be taken into consideration by administrative structures, responsible for supervising international students at the university.

\section{Introduction}

One of the priority directions in the development of modern higher education in Kazakhstan is the expansion of international cooperation in educational programs. The accession of the country to the Bologna Declaration in 2003 contributed to the involvement of many Kazakhstani universities in the international educational space. In the context of open educational space, the number of international students studying in Kazakhstani universities is increasing. Therefore, studies on the problems of international students' adjustment to living conditions and education in Kazakhstan are relevant. Investigating this topic is important for a comprehensive review of the problems of interethnic and intercultural interactions that are growing in conditions of intensive international migration in the world.

The study of the adaptation of international students is interdisciplinary in nature and occupies a special place in the works of domestic and foreign scientists. In foreign historiography, international students' adaptation and integration in the new conditions began to be studied from the second half of the twentieth century (Forstat, 1951; Davis, 1960). The theoretical approaches to this problem are based on the concept of cultural shock developed by the American anthropologist K. Oberg (Oberg 1960). In foreign works, much attention is paid to students' cultural adaptation problems in a new socio-cultural environment (Furnham, 2004; Cemalcilar et al., 2005; Brown \& Holloway, 2007; Williams \& Johnson, 2011). Among them, an international study conducted in 11 countries - the United Kingdom, Brazil, Canada, France, Germany, Hong Kong, Japan, India,

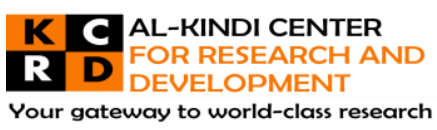

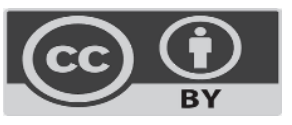

Published by Al-Kindi Center for Research and Development. Copyright (c) the author(s). This open access article is distributed under a Creative Commons Attribution (CC-BY) 4.0 license 
Iran, Kenya, and the USA - deserves special attention (Klineberg \& Hull, 1979). This collective work analyzes the friendship, national and ethnic relations of international students, immigrants from different countries. Western historiography also extensively examines the problems of international students' physical and mental health status in the process of adapting to a new environment (Bradley, 2000; Sümer et al., 2008; Molinsky, 2007; Tung, 2011). Various aspects of the adaptation and integration of international students in the host society are being studied in many branches of science. Modern Russian studies on the issues of adaptation of international students are represented by the works of sociologists (Vitkovskaya \& Trotsuk, 2005; Dorozhkin \& Mazitova, 2007; Camara, 2012), teachers (Bykova, 2008; Kulikova, 2015), psychologists (Jamirdze, 2012; Ivanova \& Titkova, 1993) and other specialists.

\section{Students' adaptation at WKMU}

WKMU has been actively developing international cooperation for a long time, including attracting international students to study. 294 international students from India (45 girls, 249 boys) study at the university, 50 first year, 99 second year, 92 third year, 46 fourth year, and 7 fifth-year students. In this regard, the urgent task for the university is to organize an effective educational process for international students, complying with quality standards. This task is complex and multifaceted. The work of teachers in WKMU is designed so that the requirements for all categories of students, both local and foreign, are the same. Teachers of the departments work within the framework of the Law on Education and the Bologna system. Everyone understands that working with students from other countries has its characteristics, which begins with adaptation to life in the conditions of Kazakhstan, new requirements for studying at a higher educational institution.

For a successful adaptation of international students, the university should have a program to support international students to get to know the culture, regional traditions, and features. The educational process in WKMU should be focused on the personal formation of international students, on the development of their cognitive, creative potential. This can be facilitated by a structured system of student public associations. Since 2018 in WKMU, a project "Program for Supporting International Students and Language Mentoring of teaching staff of clinical subjects with the English language instruction" has been functioning. The project aims to further promote modernization and sustainable development of education and training systems and improve teachers' skills. The program aims to support international students by studying the process of adapting Indian students to new socio-cultural conditions and introducing language mentoring of teaching staff with the English language of instruction. Now, the program determines the specifics of the psychological, socio-cultural and academic adaptation of international students in the new socio-cultural conditions and the current state of the work of teaching staff of clinical subjects with the English language of instruction (Karimsakova, 2019; Frencken, 2019).

While universities often provide support services for international students, the personal stories of some international students, identifying challenges, and strategies to overcome them can be helpful to other international students. We aimed to determine the peculiarities of international students' adaptation at the WKMU to university reality, which will allow the university administration to manage and organize all forms of international students' life more reasonable and effective.

\section{Methodology}

In the framework of the project, a study was conducted by the project's research staff among the international students of the WKMU in May 2019. Participants included 80 (68 males and 12 female) Indian students (M age=20.0 years). Inclusion criteria for the sample were participants in their second year of medical studies. Eighty completed questionnaires were returned, resulting in a response rate of $80.8 \%$. Sampling was therefore regarded as convenience sampling since all returned questionnaires were included in the sample.

The developed questionnaire was aimed at assessing the adaptability of international students. Most of the questions in the questionnaire included additions and comments, which made it possible to obtain not only dry statistics but also an emotional attitude to the subject of the study. The questionnaire included the following questions:

1. Whom do you contact if you have any problem at the University?

2. Do you need the free help of a psychologist at the university?

3. Would you like the University to organize additional courses in Russian, Kazakh and English language for you?

4. What problems do you have when dealing with local students? Would you like to spend your leisure time with local students of another nation and culture? Please explain your opinion?

5. What do you think is your level of Russian, Kazakh and English language enough?

6. Do you have difficulties in mastering educational material? Why?

\section{Results and discussion}

The survey results demonstrate that most students contact the tutors of their groups (75.8\%). In rare cases, students contact senior international students $(3.3 \%)$ or their subject teachers $(10.1 \%)$. Some of the respondents indicated in the questionnaires

Page | 32 
that they contact the Dean's office of the Faculty of General Medicine for help only with problems associated with their studies (9.1\%). As might be expected, some students think that they have no problems at all (2\%).

At the time of the conducted study, the structure of the university did not include a special unit for managing groups of international students. Correspondingly, international students could not go to the Dean's office in case of any problems, as local students do. This placed a great burden on the tutors of the groups whose functions do not include dealing with various, sometimes specific, issues of students. According to the Academic Policy of WKMU, a tutor is a person assigned to a group of students, who provides the functions of an academic mentor, participates in the formation and implementation of an individual training plan, provides guidance to the educational and scientific activities of the student. The tutor is appointed from among the faculty of teaching departments. International students may face many difficulties in their daily life. Coming to a new country, international students are faced with the reality of needs: finding a particular place, finding banks to deposit and withdraw money and transportation by finding buses or ordering taxies. Surviving in a new community is the first lesson they have to deal with, and they need to have a support system when they newly arrive. So in these cases, most of the time tutors help the students.

Until September 2019, the Dean's office of the Faculty of General Medicine at WKMU managed international students and local students. Specialists working in the dean's office do not speak English fluently. As a result, international students faced language problems since they did not speak Kazakh or Russian. To prevent students from having such problems, teachers who speak English are appointed as tutors of groups of international students.

Most international students have a low level of awareness of Kazakhstan's political, economic and social systems; about the norms, customs, traditions, and culture of the people, about the existing system of higher education in the country. For the first time, the problem of internationalization and the need for communication with speakers of different social, ethnic, national norms and cultures arises for most students. The study found that in addition to the assistance provided by tutors, subject teachers and senior students, international students need specialized help from a psychologist (58.6\%), as many students face adaptation problems at the university. The rest of the students indicated that they did not need the help of a psychologist (39\%). An analysis of the problems faced by students showed that the most significant barrier when interacting with local students is language competence (60\%). More than half of students say that their Russian and Kazakh languages are insufficient (68\%). Many students would like to learn to speak the Kazakh and Russian languages, as they encounter language difficulties every day when shopping and interacting with residents.

International students show great interest in the culture of Kazakhstan. They would like to participate in joint activities with representatives of non-native culture, as this would help them adapt to a foreign country (80\%). According to international students, local students are very friendly and open. Therefore, the main wishes of international students to the university administration are reduced to creating conditions for communication with local students and teachers who do not speak the English language, i.e. the organization of courses of the Russian and Kazakh languages (75\%) and cultural activity for international students (80\%). The rest of the students said they did not need to organize language courses for them (25\%) and they are not interested in spending their leisure time with local students (20\%).

Most respondents indicated that the main problem in mastering educational material is the subject teachers' language competence, i.e. not all university teachers are fluent in English (71\%). The problem arises when teachers cannot explain learning material to the student, thus focusing more on self-study. Some students can cope with mastering educational material (29\%). Assessment methods also differ in the system of education of India and Kazakhstan. In the educational system of Kazakhstan, multiple-choice tests are mainly used for the midterm and final exams. According to the students, teachers in India do not often use multiple-choice tests to assess student knowledge. Indian teachers prefer oral interviews or practical exercises.

The main reason that students study in Kazakhstan and not in India is the tuition fee. Obtaining a higher medical education in Kazakhstan is cheaper than in India. International students cannot escape the cultural shock and change their experience during their studies in Kazakhstan. Hence, these changes can be attributed to the acculturation process. These changes occur across the physical, biological, cultural, social relationship, and psychological (behaviour and mental health status) factors. International students experience a range of adjustment issues that can impact their study and overall experience. While universities often provide support services for international students, the personal stories of international students, identifying challenges, and strategies to overcome them can be helpful to other international students.

International students, being representatives of different cultures, can psychologically differ greatly from compatriots. This should be recognized by teachers and psychologists, teaching and support staff with whom international students interact in the learning process at the university. The behaviour of international students should not be perceived as strange and 
incomprehensible, and the values and norms of a different culture should not cause shock. This allows not only to recognize but also to accept differences, to get rid of prejudices and negative stereotypes associated with representatives of other ethnic cultures. We assume that support aimed at creating social and psychological conditions for the successful learning and development of a student in the educational process (Vitkovskaya, Trocuk, 2005), can be helpful in this respect.

Cultural activity should be mandatory at the university to provide the correct and healthy immersion of a foreign student in a new social environment. Cultural activities are carried out through concerts, national dance and song contests, creative contests (painting, photography, poetry, prose), round tables, volunteer activities, developmental and educational events, etc. An international student, taking part in various types of events, can reveal his talent, escape from learning activities, develop his creative skills, and occupy his niche in extracurricular activities. Events involving free and disinterested participation of students develop a long sense of conscience. Charity events are aimed at collecting tangible and intangible funds. International students can help not only their compatriots but also take care of other people. Participating in actions on a volunteer basis, students, as a rule, subsequently try to be more open to the problems of others, organize their actions.

\section{Conclusion}

We aimed to determine the peculiarities of international students' adaptation to university reality at the WKMU, which will allow the university administration to manage and organize all forms of international students' life more reasonable and effective. The focus of the study was on the socio-cultural dimension of adaptation. Based on the results of the study, we assume that Indian international students at the West Kazakhstan Marat Ospanov Medical University face challenges at different levels. The main challenges encountered by international students at WKMU are language competence, the difference in assessment, and education systems in India and Kazakhstan. These results go in line with though can contribute to modernizing study plans and assessment techniques considering the needs of international students.

Some limitations of this study should be stated. Our conclusions are based on self-assessment of international students from the same medical university and therefore, the results may be biased (overestimation and/or underestimation).

Research results allow us to make conclusions on the support programme organized by the university staff. Along with the assistance provided to the international students by the university, they need the help of psychologists on various aspects. They are interested in the country's culture where they live and study, wish to be engaged in cultural activities, and master the local language. Thus, the adaptation program implemented at WKMU facilitates the process of international students entering the new culture. The participation of international students in the public life of the university allows them to feel more comfortable in the socio-cultural space of the university. Various forms of extracurricular activities contribute to the development of skills of intercultural interaction of international students in the new socio-cultural environment.

A favourable condition for the socio-cultural adaptation of international students at WKMU is the organization of intercultural interaction and cooperation of students in the educational and social space of the university. Involvement with Kazakhstani peers is a very important aspect of international students' successful adaptation to university. Therefore, future studies can address the interaction between Indian international students and host groups of peers. Moreover, we plan to investigate the specifics of international students' psychological and academic adaptation in the Kazakhstani university setting.

\section{References}

[1] Bykova, T. L. (2008). Osobennosti social'noj i professional'noj adaptacii inostrannogo studenta k rossijskim usloviyam obrazovaniya (Specifics of social and professional adaptation of a foreign student to Russian conditions of education). Sibirskij pedagogicheskij zhurnal, 11, 52-56.

[2] Davis, F. J. (1960). Cultural perspectives of Middle Eastern students in America. Middle East Journal, 14, 256-264.

[3] Dorozhkin, YU. N., Mazitova, L. T. (2007). Problemy social'noj adaptacii inostrannyh studentov (Challenges in social adaptation of international students). Sociologicheskie issledovaniya, 3, 73-77.

[4] Forstat, R. (1951). Adjustment problems of international students. Sociology and social research, 36, 25-30.

[5] Frencken, H. M. (2019). Program for Supporting International Students and Language Mentoring of Teaching Staff of Clinical Subjects with the English language Instruction. West Kazakhstan Medical Journal, 61 (4), 259-265.

[6] Furnham, A. (2004). International students: Education and culture shock. Psychologist, 17 (1), 16-19.

[7] Ivanova, M. A., Titkova, N. A. (1993). Social'no-psihologicheskaya adaptaciya inostrannyh studentov pervogo goda obucheniya $v$ vuze: metodicheskie rekomendacii (Social and psychological adaptation of international students of the first year of study at the HEl: methodical guidelines). SPb.: SPbGTU.

[8] Jamirdze, N. K. (2012). Psihologicheskie osobennosti adaptacii inostrannyh studentov v vuze (Psychological specificity of adaptation of international students at HEI). Integrativnyj podhod k psihologii cheloveka i social'nomu vzaimodejstviyu lyudej, 73-84.

[9] Karimsakova, A. S., Kuzembayeva, G. A., Kupenova, A. A., Yermenova, K. K., Kanlybayeva, A. U. (2019). Problemy obucheniya innostrannyh studentov na anglijskom yazyke (na primere ZKMU imeni M. Ospanova) (Challenges of teaching international students in English (based on the example of WKMU). West Kazakhstan Medical Journal, 61 (2), 131-140.

[10] Klineberg, O., Hull, W. (1979). At a foreign university: An International Study of Adaptation and Coping. New York: Praeger, 211 p. 
[11] Kulikova, O. V. (2007). Problema adaptacii inostrannyh studentov v processe obucheniya v rossijskom vuze (Problem of adaptation of international students in the process of study at Russian $\mathrm{HEI}$ ). Zhurnal nauchnyh publikacij aspirantov $i$ doktorantov. URL: http://jurnal.org/articles/2007/psih4.html

[12] Molinsky, A. (2007). Cross-cultural code-switching: The psychological challenges of adapting behavior in foreign cultural interactions. Academy of Management Review, 32 (2), 622-640.

[13] Oberg, K. (1960). Culture Shock. Practical Anthropology, 7, 177-182.

[14] Sümer, S., Poyrazli, S., Grahame, K. (2008). Predictors of depression and anxiety among international students. Journal of Counselling \& Development, 86, 429-437.

[15] Tung, W. (2011). Acculturative stress and help-seeking behaviors among international studens. Home Health Care Management Practice, 23, 383-385.

[16] Vitkovskaya, M. I., Trocuk, I. V. (2004). Adaptaciya inostrannyh studentov k usloviyam zhizni i ucheby v Rossii (na primere RUDN) (Adaptation of international students to conditions and study in Russia (based on the example of RUDN)). Vestnik RUDN. Seriya Sociologiya, -6-7, 267282.

[17] Williams, C. T., Johnson, L. R. (2011). Why can't we be friends? Multicultural attitudes and friendships with international students. International Journal of Intercultural Relations, 35 (1), 41-48. 